Rajna Dragićević

\title{
DICTIONARIES OF ASSOCIATIONS OF SLAVIC LANGUAGES IN SEMANTIC STUDIES
}

\begin{abstract}
The responses to stimuli old, stupid and beautiful from dictionaries of associations of Serbian, Russian and Bulgarian language are analyzed, similarities and dissimilarities between them are emphasized and possible usage of comparative investigations of associations in semantic studies of Slavic languages, Slavic culture and conception of Slavic nations is suggested.
\end{abstract}

\section{KEYWORDS}

dictionaries of associations; lexicography; semantics; Slavic languages

\section{Introduction}

The usual method used in order to investigate meanings and lexicographic description of lexemes is to excerpt the material from the various sources, for example literature, newspapers, reference books, handbooks, etc., or take the examples from an electronic corpus. The next step would be to sort out collected material - to separate primary and secondary meanings, according to the context in which the word was used. Two things have very important roles in this process: 1) so called semantic position of a lexeme (GORTAN-PREMK 2004, 49-58), and 2) number of citations by which a meaning is confirmed. Semantic position of a lexeme is realized in its primary meaning if there is no other word preceding or following it, so called the semantic determiner, which distinguishes primary meaning from all other meanings ${ }^{1}$.

1 If we say, for example, The house is on the hill, it is clear that lexeme house is used in its primary meaning, because there is no other word used that would suggest that house has some other meaning. In the example *She married into a house of Petrovic's, the noun Petrovic is a semantic determiner, which 
Number of citations plays a significant role in determining the primary meaning of a lexeme, because analyses show that primary meanings of lexemes are confirmed by a large number of citations.

We are very often hesitant in determine whether primary meaning is the one from etymologic point of view, or the one more widely used. Furthermore, in some instances it is very difficult to determine which of the two meanings is more typical if both are confirmed with numerous citations ${ }^{2}$. In determining typical, primary meanings of lexemes, dictionaries of associations could be of great help in lexicography, lexicology and semantics. ${ }^{3}$

In the analyses of meanings of such words as adjectives and verbs, the primary meaning is determined by finding typical nonlinguistic situation, which is in connection with the meaning of the lexeme being analyzed. Adjectives such as brave, sincere, faithful may be associated to various persons in various situations, but to find the primary meaning we have to analyze which are basic and typical situations these characteristics are identified by, as well as to identify the typical participants in these situations. The most reliable sources to resolve this are surveys of associations, i.e. dictionaries of associations.

In one of the surveys conducted about the associations (DRAGIĆEvić 2001, 175176) it turned out that the speakers of Serbian language associate brave with soldier, faithful with husband or wife, cunning with merchant and politician, etc. So typical braveness for Serbian speaker is displayed in war, typical faithfulness is associated with marriage and typical cleverness with merchandize and politics. Therefore, the results of this survey may be successfully used in lexicography when defining adjectives brave, faithful, cunning, etc in monolingual dictionaries. The speaker's associations themselves reveal the primary meanings of these adjectives. Furthermore, less frequent associations reveal other meanings and the frequency of responses determines hierarchy of these meanings.

reveals a different meaning of the word house - a family (in Serbian this secondary meaning of the word house (kuća) is not so restrictive as in English).

2 For example, from synchronic language perspective it is not very clear which one is the primary meaning of the adjective sour (kiseo). We can say that sour in These plums taste sour and *He is pretty sour today have equal status. Lexicographers would choose the first example as primary, because the meaning of the adjective sour in second example evolved from the meaning of sour in first example. But, is this always the most imoprtant criterium?

3 In examining the role of tests of associations and dicritonarioes of associations in semantic research, we devoted a series of researches from which a book was written, see DRAGIĆEvić 2010. See also Dragićević and Stefanović (2013). In Slavic countries, an associative lexicography is becoming increasingly intensified, which cannot be said for the rest of the world. Multilingual associative dictionaries are also of special importance for linguistic and linguocultural studies. Particularly significant is the Slavic Dictionary of Associations (UfIMTSEVA ET AL. 2004). Unfortunately, this great and useful effort of linguists from Slavic countries is not observed in the world. Recently, one of the rare books on verbal associations (MEARA 2009) has been published in the U. K. and there is no mentioning of Slavic associative lexicography or achievements in linguistic research of associations. 
Thus, the nonlinguistic experience (social, political) makes us believe that politicians are cunning. This nonlinguistic experience characterized by society we live in shapes our point of view. That is why cunning is the most associated with politicians and merchants in Serbia. Through associations, psychological and cognitive processes, nonlinguistic experience interwove with language, primarily with semantics.

Primary meaning of the adjective cunning should be defined (in lexicography) or analyzed (in semantics) having in mind situation of buying and selling (interaction between seller and buyer) or some political action (and interaction between two politicians, i.e. politician and social group he is addressing to).

\begin{tabular}{c|c|c} 
& & \\
\hline $\begin{array}{c}\text { Sphere of nonlinguistic, } \\
\text { real experience }\end{array}$ & $\begin{array}{c}\text { Sphere of associative, } \\
\text { psychological experience }\end{array}$ & Language sphere
\end{tabular}

The speakers of other languages from different social environments could have different nonlinguistic experience, which is variously expressed in their languages.

\section{The aim of this work}

The aim of this work is to investigate this phenomenon in a smaller scope, using material form Serbian, Russian and Bulgarian dictionaries of associations (PIPER et al. 2005, KARAULOv et al. 1994-1996, BALTOVA et al. 2003) - the reactions of respondents to three stimuli - old, stupid and beautiful will be examined and analyzed in respect of how they reflect on meanings of the adjectives-stimuli in these three Slavic languages. Only the most frequent responses will be examined, specifically: 1) those which are associated with persons; 2) and those which are associated with human characteristics and are in synonymic, antonymic, hyponymic, or some other relation to stimulus. The responses with frequency 1 will not be taken into account. It is presumed that Serbs, Russians and Bulgarians have had similar social and political environment, which could shape similar point of view, the way of thinking, rationalizing. Still, they are three different cultural backgrounds, which could leave traits in social and linguistic environment.

\section{Analysis}

Old. This adjective as a stimulus appears in all three dictionaries. It produced 237 different responses in the Russian dictionary of associations, out of that 155 with 
frequency 1 (from 1065 respondents); in the Bulgarian dictionary there are 221 different responses and 169 with frequency 1, (from 557 respondents); and in Serbian 191 different responses, 137 with frequency 1 (from 800 respondents). This indicates a large number of different responses, but three the most frequent can be singled out. In Serbian and Bulgarian language, the most frequent responses are young, old man and man (respectively) and in Russian language old man, house and young. In Bulgarian dictionary there is no house as a response and in Serbian there are only two responses. These responses are not a surprise. There is a strong associative bond in mental lexicon between antonyms, so, it is expected that most frequent response to old is young. Also, it is expected that an adjective frequently produces syntagmatic responses, first of all nouns. Thus, the response old man is expected because it represents the stereotype syntagma; stimulus old denotes human characteristics.

All other more frequent responses concerning people show that typical response is old man, granny, etc. In Bulgarian and Russian language responses are diverse. For Bulgarians old is man but also soldier, fool, gambler, wise man and in Russian man, friend, fool, soldier, husband, father, teacher, devil and servant. It can be concluded that in Serbian language adjective old associates only to its primary meaning, ${ }^{4}$ where other meanings are considerably lower in hierarchy, and in speaker's mind they are activated only within a context. In Russian and Bulgarian besides the primary meaning, other important roles play secondary meanings, which are easily triggered in respondents' associations ${ }^{5}$. Some more frequent responses in Bulgarian and Russian respondents are quite unusual for Serbian respondents (for example: soldier).

In all three ethnicities oldness is associated with experience, wisdom and also tiredness. Russians associate to oldness with positive responses, such as wise, smart, good, in distinction from Bulgarians who besides wise associate sick, unhappy and helpless. Serbs, like Bulgarians, associate rather negative, adding to a negative list (beside helpless, exhausted, wrinkled) also boring. It is interesting that Serbs like Russians associate also kindness.

Investigating associations in all three dictionaries it is noted that there is an ambivalent attitude toward oldness in all three cultures. Oldness is respected to an extent and it is believed that it brings wisdom, experience, kindness, but at the same time also brings wrinkles, sickness, helplessness and exhaustion. According to material form dictionaries of associations it seems like Russians have more understanding, supportiveness, humaneness towards old men than Bulgarians or Serbs have.

Stupid. This adjective as a stimulus appears in all three dictionaries. In the Serbian dictionary there were 257 different responses and out of that 181 with fre-

$4 \quad$ RMS defines primary meaning of old as who lived for many years, who passed the age of best physical conditions; not young.

5 For example, at RMS: longtime: an old friend; that belongs to ancient times: an old soldier 
quency 1, from 800 respondents; in the Russian dictionary there were 187 different responses and 136 with frequency 1, from 527 respondents; and in the Bulgarian dictionary there were 250 different responses and 191 with frequency 1, from 583 respondents. This shows that most diverging responses are those from Bulgarian respondents (approximately $32 \%$ of different and $23 \%$ with frequency 1 ). Larger number of different responses shows unstable status of a stimulus in a mental lexicon, and thus the most stable status has the adjective stupid in Serbian language. As in case of most frequent responses on stupid we have the same situation with the adjective old - the most frequent are antonyms and synonyms and the nouns with common meanings. Again, Bulgarians and Serbs associate with the same three responses: in Serbian those are smart, man, narrow-minded, dull and Bulgarians man, smart and dull. Russian responses are similar: man, smart, lunatic.

Prototypical representatives of this characteristic for Serbs according to the dictionary are student, blonde, Bosnian and also policeman, politician etc. There is obviously a relation between respondents' reactions and jokes. It is not clear whether jokes are result of general opinion about Bosnians/policemen as stupid men, i.e. blonde as a stupid woman, or general opinion, i.e. prototype of stupid man and woman is a result of jokes about them. Prototypical representatives of stupid for Russians are boy, child, king, husband, student, young man, wise guy, friend. It is obvious that there are no very frequent responses which could characterize a specific social environment of Russia. For Russians, stupidity is a characteristic mostly of young people (children, youth, in distinction from wisdom which is a characteristic of old people) and students. Bulgarian responses are closer to Russian than Serbian. The relation between stupidity and students is more likely universal, or at least in this case is expected since the respondents were students.

Serbs to stimulus stupid associate (beside synonyms narrow-minded, dumb, rude) miserable, uneducated, ugly, naïve, good, inept, unhappy, happy. Russians' responses were mostly syntagmas, so there were a few responses as adjectives denoting human characteristics: small, naïve. Bulgarian responses were: dumb, funny, ignorant, good, unhappy, naive, innocent. The responses show in all three cases that there is a common belief that a good person is in fact naive and stupid, as well as that somebody is happy because he is not able to observe life problems.

We conclude that in all three environments stupidity is similarly felt, but responses from Serbian respondents are results of the national humor and Serbian point of view in general.

Beautiful. This adjective as a stimulus appears in all three dictionaries 6 . In Serbian dictionary there were 245 different responses and out of that 165 with frequency 1 , from 800 respondents; in Russian dictionary there were 169 different responses

6 In the Russian dictionary of associations, the word analyzed is прекрасный, which is the synonym that reflects beauty of stronger intensity. 
and 125 with frequency 1, from 494 respondents; and in Bulgarian dictionary there were 232 different responses and 170 with frequency 1 , from 581 respondents.

The most frequent responses for Serbs and Bulgarians match (Serbs: ugly, man, boy; Bulgarians: male, ugly, man, in distinction from Russians day, sex, man). The prototypical representatives with characteristics of beauty are: for Serbs young man, I, girl, Apollo, God; for Russians young man, girl, husband, prince; for Bulgarians: male, woman, God, child, fashion model. To adjective beautiful Serbs associate following characteristics: pleasant, handsome, attractive, tall, good, stupid, shallow, perfect, conceited; Russians: wonderful, good, clean, dangerous; and Bulgarians: smart, good, wonderful, stupid, pleasant, tall, young and self-centered. Serbian and Bulgarian responses match to a great extent - beauty concerning physical attraction involves tallness, youngness, perfection and harmony, but at the same time beautiful people are self-centered, conceited, shallow and stupid. There is an ambivalent attitude toward this characteristic, from deepest respect to loathing. It is no surprise that on stimulus beautiful there is a response good in all three languages, as the investigation in Serbian language shows that because of the semantic oversaturation on secondary meaning level these two adjectives are synonyms (DRAGIĆEVIĆ 2001, 195-201).

\section{Conclusion}

This analysis leads us to a conclusion that there is a great similarity in associations of Serbs, Bulgarians and Russians. Also, it shows that there are cultural, social and political bonds between those nations. Surprising is a similarity between Serbian and Bulgarian responses, which may indicate almost identical point of view of Serbs and Bulgarians.

In the Introduction of Bulgarian dictionary of associations N. V. Ufimtseva talks about the nucleus of language knowledge. It constituted of items which interact to a great extent with other items of an association set. This can be investigated by analyzing material from the dictionaries of associations of several languages. N. V. Ufimtseva came about 30 lexemes that represent nucleus of language knowledge of Russians, Belorussian, Bulgarians and Ukrainians. The first five items are: life, man, house, love and joy. N. V. Ufimtseva has noted that there is a large percentage of interaction between the nucleuses of the language knowledge of Belarusians and Ukrainians.

For a semanticist every frequent association reveals a semantic component of a stimulus or its syntagmatic, i.e. paradigmatic relation with the other units of a lexi$\mathrm{cal}$ system. For that reason, every frequent association is an important semantic information. This limited comparative analysis shows: 1) investigating adjective old, responses revealed the status of the secondary meanings within polysemantic struc- 
ture of the lexeme. In Serbian language the primary meaning of the adjective old is dominant, because associations are always related to that meaning. In distinction from Bulgarian and Russian where some secondary meanings have a significant position in the polysemantic structure, because of the numerous associations relate to those meanings; 2) investigating adjective stupid, responses revealed a significant differentiation in Bulgarian language in relation to Serbian and Russian, which shows a lower degree of stability of this lexeme in the mental lexicon of Bulgarian language. It is possible that a larger number of different responses includes implicitly a larger number of meanings; 3 ) the responses in all three languages show that respondents have an ambivalent attitude towards oldness and beauty. The information about the status of those characteristics as welcomed and unwelcomed at the same time, plays an important role in semantic classifications of those adjectives.

This short analysis showed that dictionaries of associations may significantly improve methodology of investigation of Slavic languages, cultures, beliefs and stereotypes as well.

\section{REFERENCES}

Baltova, Penka et al. 2003. Bălgarski asociativen rečnik, pravi obraten. Sofija: Sofijski universitet „Sv. Kliment Ohridski“, Ruska akademija na naukite.

DragićEvić, Rajna. 2001. Pridevi sa značenjem ljudskih osobina u savremenom srpskom jeziku, tvorbene i semantička analiza. Beograd: Institut za srpski jezik SANU.

DRAGIĆEvić, Rajna. 2007. Leksikologija srpskogjezika. Beograd: Zavod za udžbenike.

DrAGićEvić, Rajna. 2010. Verbalne asocijacije kroz srpski jezik i kulturu. Beograd: Društvo za srpski jezik i književnost Srbije.

Dragićević, Rajna - PiPer, Predrag - Stefanović, Marija. 2012. Obratni asocijativni rečnik. Beograd: Beogradska knjiga, Službeni glasnik.

DraGiČEviČ, Rajna - Stefanovič, Marija. 2013. O slavjanskoj associativnoj leksikografii. Slavjanskaja leksikografija. Meždunarodnaja kollektivnaja monografija. Otv. Red. M. I. Černyševa. Moskva: Meždunarodnyj komitet slavistov, Komissija po leksikologii i leksikografii; Nacionalnyj komitet slavistov Rossijskoj Federacii; Institut russkogo jazyka im. V. V. Vinogradova RAN, 390-405.

Gortan-Premk, Darinka. 2004. Polisemija i organizacija leksičkog sistema u srpskome jeziku. Beograd: Zavod za udžbenike.

KARAULov, Jurij N. et al. 1994-1996. Associativnyj tezaurus sovremenogo russkogo jazyka. T. I. Russkij assoativnyj slovar. Kn. 1. Prjamoj slovar: ot stimula k reakcii. 1994. Kn. 2. Obratnyj slovar: ot reakcii k stimulu. 1996. Moskva: Rossijskaja akademija nauk.

MeArA, Paul. 2009. Connected Words. Word associations and second language vocabulary acquisition, Amsterdam/Philadelphia: John Benjamins Publishing Company.

PIPER, Predrag at al. 2005. Asocijativni rečnik srpskoga jezika. Beograd: Beogradska knjiga, Filološki fakultet, Službeni list. 
RMS. 1967-1976. Rečnik srpskohrvatskoga književnogjezika. I-VI. Novi Sad: Matica srpska.

Ufimtseva, Natalja V. et al. 2004. Slavjanskij associativnyj slovar, russkij, belorusskij, bolgarskij, ukrainskij. Moskva: Ministerstvo obrazovanija i nauki Rossijskoj Federacii, Moskovskij gosudarstvennyj lingvističeskij universitet, Rossijskaja akademija nauk.

\section{Rajna Dragićević}

- Department of Serbian with South-Slavonic Languages

University of Belgrade, Faculty of Philology

Studentski trg 3, 103932 Belgrade

Republic of Serbia

rajna.dragicevic@fil.bg.ac.rs 